\title{
Memory and history: Oral techniques in the East African context
}

\begin{tabular}{|c|c|}
\hline $\begin{array}{l}\text { Author: } \\
\text { Julius M. Gath }\end{array}$ & $\operatorname{ogo}^{1,2,3}$ \\
\hline $\begin{array}{l}\text { Affiliations: } \\
\text { 1Department } \\
\text { Spirituality, } \mathrm{Cr} \\
\text { Missiology, Fa } \\
\text { Humanities, U } \\
\text { South Africa, I } \\
\text { South Africa }\end{array}$ & $\begin{array}{l}\text { f Christian } \\
\text { urch History, } \\
\text { culty of } \\
\text { niversity of } \\
\text { retoria, }\end{array}$ \\
\hline $\begin{array}{l}{ }^{2} \text { Department } \\
\text { and Religious } \\
\text { Faculty of Hur } \\
\text { Kenyatta Univ } \\
\text { Mombasa, Ke }\end{array}$ & $\begin{array}{l}\text { ff Philosophy } \\
\text { Studies, } \\
\text { nanities, } \\
\text { ersity, } \\
\text { hya }\end{array}$ \\
\hline $\begin{array}{l}{ }^{3} \text { Faculty of Th } \\
\text { University, An } \\
\text { United States }\end{array}$ & $\begin{array}{l}\text { ology, ANCCI } \\
\text { larillo, Texas, }\end{array}$ \\
\hline $\begin{array}{l}\text { Correspondin } \\
\text { Julius Gathog } \\
\text { jumgathogo@ }\end{array}$ & $\begin{array}{l}\text { g author: } \\
\text { gmail.com }\end{array}$ \\
\hline $\begin{array}{l}\text { Dates: } \\
\text { Received: } 18 \text { J } \\
\text { Accepted: } 16 \\
\text { Published: } 14\end{array}$ & $\begin{array}{l}\text { an. } 2021 \\
\text { Apr. } 2021 \\
\text { July } 2021\end{array}$ \\
\hline $\begin{array}{l}\text { How to cite th } \\
\text { Gathogo, J.M., } \\
\text { and history: } \\
\text { in the East Afr } \\
\text { HTS Teologies } \\
\text { Theological St } \\
77(2) \text {, a6477. } \\
\text { org/10.4102/l }\end{array}$ & $\begin{array}{l}\text { is article: } \\
\text { 2021, 'Memory } \\
\text { ral techniques } \\
\text { ican context', } \\
\text { Studies/ } \\
\text { udies } \\
\text { https://doi. } \\
\text { its.v77i2.6477 }\end{array}$ \\
\hline $\begin{array}{l}\text { Copyright: } \\
\text { (c) 2021. The } \\
\text { Licensee: AOS } \\
\text { is licensed un } \\
\text { Creative Comr } \\
\text { Attribution Lic }\end{array}$ & $\begin{array}{l}\text { Iuthors. } \\
\text { IS. This work } \\
\text { der the } \\
\text { nons } \\
\text { ense. }\end{array}$ \\
\hline Read online: & \\
\hline 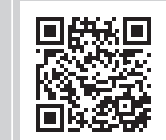 & $\begin{array}{l}\text { Scan this QR } \\
\text { code with your } \\
\text { smart phone or } \\
\text { mobile device } \\
\text { to read online. }\end{array}$ \\
\hline
\end{tabular}

Author:

Affiliations:

Department of Christian Missiology, Faculty of Humanities, University of South Africa, Pretoria, and Religious Studies, Faculty of Humanities, Kenyatta University,

${ }^{3}$ Faculty of Theology, ANCCI University, Amarillo, Texas,

Corresponding author: Julius Gathogo,

Dates:

Accepted: 16 Apr. 2021

How to cite this article: (Mathogo, JM., 2021, Memory in the East African context', HTS Teologiese Studies/ Theological Studies 77(2), a6477. https://doi. Copyright:

(C) 2021. The Authors. Licensee: AOSIS. This work is licensed under the Creative Commons
Some historians have always erred in ignoring oral history methods, as it is always assumed wrongly that the only reliable and trustworthy source of history is the written word. The aim of this article is to underscore the nature and significance of oral histories, which rely on the memory of the narrators. In the case of both Ngugi wa Thiong'o's and Wole Soyinka's literary works, their respective childhood experiences are well captured, as they employ both the use of postcolonial and autobiography theories in their theoretical frameworks. In its methodology, this article relied heavily on extensive literature review, oral interviews and archival sources. In seeking to demonstrate the significance of oral history for the preservation of memory and for the writing of history in Africa, the author intends to build from both the above literary works and other theohistorical materials so as to convey the message that the methodology used in chronicling East African oral history, the history of Christian doctrines, Church history or social histories will require us to go beyond postcolonial theory and the theory of autobiography in order to harvest the rich and forward-moving historiographies that remain unexplored and/or unpublished altogether.

Contribution: Memory as a critical tool that moves humanity forward is the main subject of this article. The article is relevant to the journal HTS Teologiese Studies/Theological Studies and the world of scholarship as it undertakes a multidisciplinary approach in engaging literary works with theo-historical works in order to build the case for oral techniques in modern scholarship.

Keywords: postcolonial theory; theory of autobiography; oral history technique; ancestral memories; power of memory.

\section{Introduction}

Oral history methods can be seen in the form of autobiographies, festschrifts, memoirs and novels that capture some oral information; plays and other literary works that mimic and sometimes satirise, caricature and/or mock certain unpleasant communal realities; and books and publications that capture suppressed histories as in the case of gender and colonial actualities. In view of this, this article seeks to demonstrate that oral histories are essential as they confirm, reaffirm, reinforce, correct, liberate, reconstruct, reconcile and eventually add to the historical record.

In the literary works of Ngugi wa Thiong'o (cf. Dreams in a Time of War 2010) and Akinwade Oluwole Babatunde Soyinka (cf. The Years of Childhood 1981), their respective childhood experiences are graphically captured in colonial Kenya and Nigeria. The underlying theme, in their literary works, is that childhood memories are critical in individual and societal lives. In the case of Soyinka, he grew up as a privileged child, whilst wa Thiong'o (2010) grew up as a deprived child. Both writers share a lot in common: they grew up at around the same historical time when West Africa (Soyinka) and East Africa (wa Thiong'o), and the rest of Africa, were experiencing difficult times. Autobiographical and postcolonial theories, which are also evident in theological histories and church history, focus on memory in their respective contexts. The practice of recording recollections after interviews, using archival sources, revisiting historical sites, preserving unique happenings, giving prominence to the oral sources and so on will boost our memories as a people. As this article will try to demonstrate, people whose memories are blurred or destroyed altogether, through neglect or lack of preservations, will always face the risk of extinction.

Note: Special Collection: Social Memory Studies, sub-edited by Christina Landman (University of South Africa) and Sekgothe Mokgoatšana (University of Limpopo). 
Whilst memory can be seen merely as the means to which we draw on our past experiences so as to enrich the present information, it is worthwhile to concede that the age of science and technology drives us to broaden our understanding of these experiences (Bryman 2004:21; Crotty 2003:5). This means that 'memory' is not just the term given to the processes and structures dealing with the stowing and the resultant retrieval and/or recovery of data (Crotty 2003:6). Considering that memory is crucial to all the pillars of culture (refer to religion, economics, politics, aesthetics, ethics and kinship) (Mugambi 1989:128), researchers in human and social sciences will continue to rely on oral traditions and storytelling and/or oral narrative as a critical variable, in the East African context and in the rest of the tropical Africa.

From the outset, it is worthwhile to concede that autobiographical memory is something to do with a memory system that consists of episodes recollected from an individual's life is based on experiences, events, phenomena and daily encounters - some of which reshape world history - and is periodical, timely and captures the whole essence of our being (Crotty 2003:7; Roberts 2002:3). This understanding of memory as a powerful tool in human endeavours was graphically captured by Michelle Obama as she bewailed the loss of her father, Fraser C. Robinson (1935-1991), in a speech that was delivered on 09 June 2009:

Now, my Dad didn't live to see me in the White House. He passed away from complications from his illness when I was in my twenties. And, graduates, let me tell you, he is the hole in my heart. His loss is my scar. (p. 91)

\section{She went on to say:}

But let me tell you something, his memory drives me forward every single day of my life. Every day, I work to make him proud. Every day, I stay hungry, not just for myself, but for him and for my mom and for all the kids I grew up with who never had the opportunities that my family provided for me. (Obama 2020:1)

In light of this, this presentation will attempt to address the view that even if there are many theories and methods in contemporary scholarship, autobiographical memory is critical in postcolonial scholarship as it will successfully usher in a positive reconstruction of our society.

As will be demonstrated in this article, through all the vicissitudes of life, and especially in the world of academia, oral techniques have been used across disciplines to extend knowledge. This dalliance with memory and/or oral techniques is evident in literary works, East African literature, the study of religion, autobiographical theory, leaders' memoirs, postcolonial theory, feminist theory, womanist scholarship, cultural hermeneutics, comparative religions, analytical history and oikotheology (the theology of the whole household of God) amongst other areas, so as to enrich the present information, reinforce what is already known in history and/or to build new knowledge altogether (Gathogo 2020c:52-97). Certainly, memory and its resultant oral techniques will be needed to reinforce existing literature or to clarify issues that have remained ambiguous to the society. For example, the role of Portuguese missionaries in the 15th and 16th centuries on the East African coast (Gathogo 2013a:2) will need to be revisited and rewritten from the perspective of the locals rather than from the perspectives of the European anthropologists and explorers of the time (Gathogo 2013a:167-192). For as the African saying goes, unless the Lion learns how to write, every story will glorify the Hunter. Put differently, if the Lion fails to write his or her side of the story, the Hunter will keep telling the story from his or her own perspective, for example saying that his or her medals, expeditions, bravery and other heroic acts in the jungle are the only good things.

In turn, the story of the Lion will continue to be presented as cruel, barbaric, merciless and as the de facto enemy of human well-being - hence the justification to destroy the Lion the moment an opportunity avails itself. Certainly, a court of Hyenas will always pronounce a death sentence on a Goat for serious crimes, real or imagined. Equally, if our rich oral narratives are not retrieved and subjected to the canons of modern publications, the East African context will continue to be dismissed, as in the case where European anthropologists of the 19th and early 20th centuries described the African God as a deus remotus [a withdrawn God], African religious practitioners as fetish worshippers and African religion as fetishism (Idowu 1973:51), ancestral worship, paganism, dualism, pantheism, animism, idolatry, heathenism, primitivism and polytheism, amongst others (Parrinder 1962:21).

\section{Methodology}

The methodology in this article is broad-based, as it incorporates literary works, conventional writings in human sciences, archival sources and an extensive review of the literature. In view of this, it sets out on the premise that the critical roles of outstanding East African church leaders, both Protestants and Catholics, need to be revisited from an autobiographical perspective and/or through other related methodologies. Equally, colonial and postcolonial discourses in East Africa need to be recaptured in the 21st century so as to clarify early misunderstandings and ambiguities. In this article, I will cite several cases that underscore the power of memory in academia, in the general vicissitudes of life, and in mitigating the negative factors of globalisation. Case studies of literary works and ecclesiastical histories in East Africa will certainly aid in repairing the damage. In any case, the theology of reconstruction has something to do with rewriting our own stories in a relevant and/or constructive fashion that resonates well with our collective memories as a people (Gathogo 2008:23-62). Undoubtedly, it is no longer the precept cogito ergo sum [I think, therefore I exist] of the French philosopher Rene Descartes that resonates, but rather John Mbiti's African aphorism 'I am because we are', or 'I am related, therefore I am' [cognatus ergo sum] or even the existential cognatus sum, ergo sumus [I am related, 
therefore we are] (Gathogo 2001:21). In misrepresenting and/or distorting facts, we eventually hurt the collective memory of African heritage in general, thereby wounding memory and history in our East African context. African church history is replete with such unfortunate scenarios.

\section{Oral techniques as an authentic model}

Oral history technique and/or oral methods in modern scholarship have gained broad acceptance as an authentic model in East Africa, Africa and beyond (Crotty 2003; Roberts 2002). Through oral narratives, rooted in African heritage, a person narrates his or her story as he or she knows it. Even though we may poke holes and say that narrators are biased and speak from their perspectives and that oral information wears out or erodes with time, it is worthwhile to also appreciate two things. Firstly, every historian writes or narrates from his or her own perspective, and there is no neutral human communication; hence we must underline this fundamental understanding. Secondly, any credible academic work has to adhere to the ethics of research; hence an oral researcher or historian has to be very keen when listening to those whose memories are fading because of advancing age or sickness or for any other reason (Bryman 2004:7; Crotty 2003:6). In carrying out oral research or documenting a given oral history, one has to listen to more than one person on the same subject under consideration (Bryman 2004:7). Beyond this, every data given must meet a logical threshold for it to be within the ethical standards. In other words, one may want to ask: Does it contradict another established theory that relates to the subject under consideration, and if so, where is the logic, or illogicality for that matter? In a nutshell, every credible research has to be empirically sensible; hence one cannot enforce a pedestrian stereotype and repackage it as a credible oral historical fact.

African women theologians have used storytelling and/or oral narrative techniques in scholarship to deconstruct patriarchy and eventually reconstruct womanhood and humanity in general. For as Phiri (1997) says:

The construction of womanhood by patriarchy is one of the central issues for feminist theologians globally and particularly in Africa because it has influenced the way women and the roles that women can play in African Church and society are imaged. Patriarchy has defined women as inferior to men thereby perpetuating the oppression of women by religion and culture. (p. 69)

As a tool of healing and reconciliation with a society that has unapologetically remained patriarchal, sexist and conflict-prone - as in the case of Somalia, Ethiopia, xenophobic South Africa, Mozambique, Sierra Leone, Angola, Rwanda and even after the disputed December 2007 elections, where over 1000 Kenyans lost their lives and over 400000 found themselves homeless - an effective methodology has to be put into consideration (Gathogo 2012:74-91). In such contexts that define postcolonial East
Africa and Africa at large, storytelling becomes a critical tool of healing, learning, reconciliation and more importantly a tool of recovery from both locally and foreigninduced conflicts.

In view of this, oral history technique, and more importantly storytelling, becomes an avenue of healing that creates a forum for confessing sins of commission and omission. The healing confessions seen during the Truth and Reconciliation Committee (TRC) in post-apartheid South Africa is a case in point that underscores the importance of storytelling (Gathogo 2012:74-91). Storytelling thus aids in the psychosocial reconstruction of our conflict-prone society, a phenomenon that is largely triggered by competition for the few resources at our disposal. As a technique, oral history finds itself at home with the rank and file of society as it breaks down the dichotomies of learned versus not learned, educated versus uneducated, theologians versus nontheologians - as all voices can narrate their experiences for broader analysis and general consideration. To this end, Phiri (2004) shows the justification of engaging in oral theologies amongst African women theologians and explains thus:

Storytelling is one of the powerful methodologies that African women have revived. Musa Dube has developed a unique methodology of reading a biblical story in the context of globalisation through story telling technique. Through storytelling, African women are bringing to the attention of the world their spiritual, emotional and physical suffering and the potential they have to transform their situation of oppression. It includes men in its vision and struggle for African liberation from all forms of oppression. (p. 156)

Besides African women theologians, a leading North American black theologian, James Cone (1938-2018), captures the role of storytelling in aiding our memory when he says:

Every people have a story to tell, something to say to themselves, their children, and to the world about how they think and live, as they determine their reason for being ... When people can no longer listen to the other people's stories, they become enclosed within their own social context ... And then they feel they must destroy other people's stories. (Cone 1975:102-103)

Indeed, as early as 1941, Niebuhr (1941:41ff.), the American theologian, had captured the importance of storytelling in doing theology and academia in general when he noted that a lack of memory signals that the society is not real, and therefore it is not living up to the expected norms. In his words, this type of remembering is 'a moral event' or 'a conversion of memory' (p. 42) - which alone can make genuine solidarity possible.

Certainly, African indigenous religion relied heavily on oral techniques as a means of upholding peoples' memory and eventually preserving peoples' heritage. These oral approaches of preserving memory have remained relevant right into the 21st century. In view of this, Chidester et al. (1997) have helped us to appreciate this reality by citing 
Jomo Kenyatta's book, Facing Mount Kenya. They explain thus:

Consider the example of (Jomo) Kenyatta's Facing Mount Kenya. Note that this 'facing' is a metaphor for orientation in space and time as well as for motivation. To face Mount Kenya means to think and do African without any concern for non-African opinion. The first significance of this act of indifference lies in facing towards an African centre. Implied in the act is a facing away from other centres of meaning and power. Now this is not to suggest that these other centres are denied either existence or power within their sphere of influence; it is to stress, however, that Africans recognize a space and a moment in which every other centre can only register as subordinate to an African centre. It is in this space that the core of African identity inheres. (p. 2)

The import of Chidester et al.'s (1997) position helps us to see the resilience and nature of African indigenous education, which must necessarily be in dialogue with Western education so as to earn its relevance in tropical Africa. Embracing oral skills, which are rooted in African indigenous religion, is certainly critical, as:

The popular version of African traditional religion is what Africans (including some elites, though mostly the masses) do with no regard for what Westerners, or anyone else, may or may not think about it. It is what Africans do when they are just Africans. Now this does not mean that such a practice is completely untouched by alien influences, be they religious (such as Christianity or Islam) or secular (such as modernity); what it means is that in full cognisance of their historical context Africans do what they do for their own reasons rather than to impress someone else .... (pp. 2-3)

\section{Songs and dances}

Besides oral narratives, riddles and drama, songs and dances constitute a very critical method of preserving African oral histories. Idowu (1973) reminds us that songs and dances:

[C]onstitute a rich heritage for the whole of Africa. For Africans are always singing and in their singing and poetry, they express themselves. In this way, all their joys and sorrows, their hopes and fears about the future, find an outlet. (p. 84)

For singing always becomes a forum for communicating and educating on certain issues of importance to the community. Songs and dances gain more memorable significance when they are blended with rituals, as they now communicate to both the living and to the ancestors, especially when libations are poured.

In his books African Christian Theology: An Introduction (1989) and From Liberation to Reconstruction: African Christian Theology after the Cold War (1995), Jesse Mugambi utilises the hymn-biblical text method in order to drive home his two themes of liberation and reconstruction. In particular, he uses four revivalist songs, composed in the 20th century in Europe, as a vehicle of communicating both his theology of liberation and a theology of reconstruction. In particular, he uses Elliot's (1957:58) song: 'Just as I am, without one plea, But that thy blood was shed for me, And that thou bidd'st me come to Thee, O Lamb of God, I come' (quoted from Christian Praise). Perhaps the missing link is the lack of African indigenous songs in Mugambi's schema of liberation and reconstruction.

\section{Postcolonial theory}

In regards to the African context, anticolonial movements and antislavery recollections and memories gave rise to postcolonial theory. Reading from Ngugi wa Thiong'o's works, he offers sharp critiques to the Christian missions of the 19th and 20th centuries. In his novels and books of plays, such as Dreams in a Time of War, The River Between, Petals of Blood, I Will Marry When I Want, Weep Not Child, Devil on the Cross and so on, postcolonial theory is clearly evident as he critiques missionary enterprises, colonialism, settler-missionary alliances, colonial hegemony, cultural imperialism, religious domination and conquest, and the modern versions of neocolonialism, which include corruption, the dominance of the bourgeoisie in the socioeconomic setup and so on. As he advocates for the decolonisation of the mind in his works, and in his use of postcolonial theory in general, he provides a means of defiance against exploitative, divisive and discriminative practices. In turn, elements that justify postcolonial theory are largely economic, social, political, religious, feminist and humanitarian (Mugo \& Gathogo 2018:1-16).

One of the researcher's articles, titled 'Genesis, methodologies, and concerns of African theology of reconstruction', has outlined five stages of African Christianity and African theological thinking: Christianity as propagated by the early church fathers and the Apologists before the 4th century CE, the Portuguese Christianity of the 15th to 17th centuries, the brand of Christianity that was propagated by the early missionaries of the 19th and 20th centuries, the theologies of adaptation, indigenisation or inculturation and liberation which was indeed experienced after the Bible was translated into the indigenous languages of the diverse peoples of Africa - and the emergence of theologies of reconstruction in the early 1990s (Gathogo 2008:23-62). The postcolonial theology of reconstruction, for example, emphasises inclusivity as opposed to exclusivity, bottom-up forms of development rather than a top-bottom approach:

$[P]$ roactive rather than reactive; complementary rather than competitive; integrative rather than disintegrative; programmedriven rather than project-driven; people centred rather than institution-centred; deed-oriented rather than word-oriented; participatory rather than autocratic; regenerative rather than degenerative; future-sensitive rather than past-sensitive; cooperative rather than confrontational; consultative rather than impositional. (Mugambi 1995:xv)

As a postcolonial initiative, the theology of reconstruction is seen as a strong advocate for a free postcolonial African worldview that remains hopeful for a better future and builds on the Afro-optimist trend. It advocates the end of neocolonialism, just as colonialism was conquered. Although neocolonialism is largely seen as another form of 
imperialism, where the industrialised world interferes in the sociopolitical affairs of post-independent countries, it also includes dictatorship, mismanagement of national resources and corrupt practices amongst postcolonial African nations (Gathogo 2007a:185-186). The African theology of reconstruction is oriented towards the construction of a democratic and socio-economically empowered Africa that seeks to actualise the dreams of the Pan-Africanists of the 19th and 20th century, such as Marcus Garvey, George Padmore, C.L.R. James, Léopold Senghor, Aimé Césaire, William duBois, Edward Blyden, Jomo Kenyatta and Kwame Nkrumah, amongst others. Hence, reconstruction theologies appeal strongly to the ancestral memories of the dreams of African renaissance and sociocultural rebirth, which is spiced with 'calls for rebuilding, renewal, development and theo-ethical rebirth' (Gathogo 2008:24). It is no wonder that the sources of African theology of reconstruction appeal to the memory and/or to oral and technological sources. In this case, science and technology are only critical insofar as modernity and relevance are concerned. The sources therefore are, amongst others: the Bible, science and technology, the New Partnership for Africa's Development (NEPAD), All Africa Conference of Churches (AACC), African Cultural and Religious Heritage, the history of the Christian missions in Africa and the Pan-Africanist movement of the 20th century (Gathogo 2008:23-62). Certainly, the above five stages of African Christianity and African theological thinking proceed from precolonial to postcolonial Africa. Some methodological considerations in doing an African theology of reconstruction are, amongst others: historical enquiry, inclusivity, culturalanthropological and philosophical enquiry, a multidisciplinary approach, a critical re-evaluation of biblical themes of liberation and salvation, storytelling and contextual theologising (Gathogo 2008:23-62; Mugambi 1995). To a large extent, these methodologies appeal to memory, hence signalling that the society is real and within its norms (Niebuhr 1941:43).

\section{Ngugi wa Thiong'o's Wizard of the Crow}

In this book, Ngugi wa Thiong'o nurtures our collective memory by using his novel to remind the people of East Africa and Kenya in particular, mimicking the oppressive rule of 1980s and 1990s, where one person determined the destiny of masses of people, who were subjected to being hewers of wood and drawers of water, just as the Gibeonites were condemned to servitude under the Israelites (Jos 9:21). As single-party dictatorship reigned in Kenya with an iron fist, trumped-up trials, kangaroo courts and detention without trial became Kenya's defining characteristic until fearless clergy like archbishops David Gitari, Raphael S. Ndingi Mwana a'Nzeki and Zacchaeus Okoth, bishops Henry Okullu and Alexander Muge, Rev. Timothy Njoya and other notable clergy hit back at the seemingly intolerant governing system. Equally, other members of the civil society and lawyers such as Paul Muite, Gitobu Imanyara and
Martha Karua and veteran politicians such as Oginga Odinga, Kenneth Matiba, Charles Rubia, Martin Shikuku, Raila Odinga, Koigi wa Wamwere, Mukhisa Kituyi and Prof. Wangari Maathai challenged the system and called for a laissez-faire society for all (Gathogo 2009b, 2015a).

In the Kenyan context, the so-called second liberation heroes of the 1980s and 1990s were enthused by Kenya's collective memory after drawing lessons from the Mau-Mau rebels of the 1950s and 60s. The latter dared a conventional and stronger colonial army and gallantly sought Kenya's constitutional and economic independence. Appreciating their unique positioning in history, by appealing to their ancestry, emboldened the heroes and heroines of Kenya's second liberation, a phenomenon that ushered in a democratic society. In the global context, our collective memory of Mahatma Gandhi, Abraham Lincoln, Winston Churchill, Charles Nyamiti, John Mbiti, Kwame Bediako, Pope John Paul II and Mother Theresa, amongst others, 'drives [us] forward every single day of [our lives]' (Obama 2020:1) and motivates us to swing into action and deliver the world from the hotchpotch of issues that befog it. Further recollections put the African context in the position of Moses and Aaron as they confronted the Egyptian pharaoh with the dictum ' $[t]$ hus saith the LORD God of Israel, Let my people go, that they may hold a feast unto me in the wilderness' (Ex 5:1).

In his bid to decolonise the mind, Ngugi wa Thiong'o first wrote his novel, Wizard of the Crow (2006), in his indigenous Kikuyu (African) language, which in my view demonstrates that all languages are tongues of God and no language speaker should be subjected to being a hewer of wood and drawer of water, metaphorically or in any other way. The book, which was first called Murogi wa Kagogo, was later translated to Wizard of the Crow. Ngugi wa Thiong'o brings out the imaginary Free Republic of Aburiria to prick our collective memory.

In Ngugi wa Thiong'o's novel Wizard of the Crow (Murogi wa Kagogo), one character (Nyawira) in the country of Aburiria 'seems to apotheosize Wangari Maathai' (Muhia \& Gathogo 2018:1-16). This is reminiscent of the case where Prof. Wangari Maathai fought bravely in the late 1980s and early 1990s to stop the construction of what is being framed, in the novel, as the highest building ever to be built on Earth, a building that was planned along the lines of the biblical story of the Tower of Babel (Gn 11:1-9). Wangari Maathai fought this ecologically insensitive building that the government of President Moi intended to build until Nairobi's public recreation park was spared from destruction. In Ngugi's novel, Nyawira (who represents hardworking women) risked her life and fought what was described by the government of Aburiria as that which will be an 'out-wonder [of] all the existing wonders of the world: the pyramid of Egypt, Taj Mahal, the Hanging Gardens of Babylon, the Great Wall of China etc' (Muhia \& Gathogo 2018:8). Wangari Maathai went on to win the Nobel Peace Prize in 2004 for her crusade against human rights violations and in support of 
environmental conservation. Wa Thiong'o appeals to the politics of language to show how historical factors have played a negative role in disfiguring the African memory. As noted in Gathogo (2016):

Ngugi wa Thiong'o, the well-known Kenyan novelist, dramatist and essayist, in his Something Torn and New: An African Renaissance, traces Africa's fragmentation and restoration amidst the global history of colonialism and modernity. For him, Africans in Africa and in the diaspora were subjected to the same erasure of all that preceded European conquest and colonisation. He sees similar patterns among other cultures, with the Irish and Native Americans being just two examples. Language therefore becomes critical in reconnecting conquered people to their respective cultures. In his quest for a revitalised Africa, he argues that a renaissance of African languages is an essential step in the restoration of African wholeness. He stopped writing in English in the 1970s in favour of African languages, specifically Kikuyu and Kiswahili, and ponders whether an African renaissance, following the dark ages of colonialism and apartheid, would be expressed in European languages. His foremost concern has therefore been the critical importance of language to culture. As he explores Africa's historical, economic and cultural fragmentation by slavery, colonialism and globalisation, Europhonism, the replacement of indigenous names, languages, and identities with European ones, reveals itself as a constant and irrepressible force the result of which he envisages to be the dismemberment of African memory. (p. 54)

\section{Autobiographical theory}

Wole Soyinka's (1981) book The Years of Childhood, like Ngugi wa Thiong'o's Dreams in a Time of War (Thiong'o 2010), is another treatise that appraises the power of autobiographical theory. As in postcolonial theory, noted above, the power and essence of memory run concurrently. In The Years of Childhood (1981), Akinwade Oluwole Babatunde Soyinka, popularly called Wole Soyinka, gives an autobiographical account of events in his childhood, ranging from 1934, the year of his birth, through to 1945, as he grew up in the town of Ake, Nigeria. Soyinka spent 12 years of his life in Ake before moving to Ibadan to attend a government college. His starting point is a parsonage compound, among the Yoruba people in Abeokuta. Such memories are forward moving, as they inspire his readers to appreciate a humble starting point for top achievers as the ideal preparation for a major take-off. Soyinka, the Nigerian playwright, poet and essayist, went on to be awarded the Nobel Prize in Literature, in 1986, the first sub-Saharan African to be honoured in that category.

In Ngugi wa Thiong'o's Dreams in a Time of War (2010), he demonstrates the power of memory when he takes his readers on a journey right into the colonial era, which was characterised by cultural subjugation, 'modernity' conflicts, war, tension and the troubled relationship that emerged when Christianity created a middle class versus the rural poor. In attempting to prick our collective memory, in Dreams in a Time of War wa Thiong'o presents recollections of the Mau Mau war of independence, in which tens of thousands lost their lives during the 1950s and 1960s, to demonstrate that we can dare to dream even in the worst of times. Hence, in his childhood and youthful moments, he could dare dream of a better world despite facing all sorts of danger. In employing autobiographical theory and method, Ngugi shows that human rights are sacrosanct and translate to the fact that complexities and the sociopolitical vicissitudes of life under colonialism, war and neocolonialism cannot bar the way for dreamers with a collective memory.

In Ngugi wa Thiong'o's novel Decolonising the Mind (1981, 1986), he reminisces about the dark days of Kenya's colonial history, where in 1952, African instituted schools, which allowed the use of the vernacular, were closed down following the Mau Mau (freedom fighters) skirmishes. This coincided with the declaration of a state of emergency on 20 October 1952 that lasted till 12 January 1960, when it was lifted by the British colonial government (Gathogo \& Njogu 2019). This banning of patriotic schools went hand in hand with the idea of making English the only language of instruction in schools and using it as a measure of intelligence. In other words, the better you spoke English, the more intelligent you were seen to be, as other languages were treated as inferior. Such recollections are critical in formulating and planning for a better future.

\section{Church historians and the autobiographical approach}

Church history and historians of theological and religious studies have also employed critical autobiographical theory in addressing cutting-edge issues facing society and in employing memory to move society forward. Conducting literature searches and reviews shows social-ecclesiastical publications that have employed an autobiographical approach to communicate critical matters. Such works include Nelson Mandela: 'No Easy Walk to Freedom', which is a vivid biography that takes its title from a 1953 speech in which Mandela reminded his audience that the dismantling of apartheid would not be an exercise in smooth sailing. Authored by Barry Denenberg, in 2014, it utilises an autobiographical approach and demonstrates the power of memory in moving humanity forward.

Other critical publications that utilise autobiographical theory include 'A brave one-legged general: The story of Mau Mau General Kassam Gichimu Njogu' (Gathogo 2020a:1-7), 'Karubiu wa Munyi and the making of modern Kirinyaga, Kenya' (Gathogo 2020b:1-8), 'Steve de Gruchy's theology and development model: Any dialogue with the African theology of reconstruction?' (Gathogo 2019a:307-328), 'Mwendoni-ire Z K: Reconstructing the memory of Z. K. Matthews in Southern Africa (1901-68)' (Gathogo 2019b:1-16), 'Theological education in tropical Africa: An essay in honour of Christina Landman and a Kenyan perspective' (Gathogo 2019c:1-9), 'The use of indigenous resources in environmental conservation in Ngugi wa Thiong'o's Murogi wa Kagogo: a religio-cultural perspective' (Muhia \& Gathogo 2018:1-16), 'Nahashon Ngare Rukenya and the moral re-armament in Kenya: The 
turning point and the post Mau-Mau war reconstruction (1959-1970)' (Gathogo 2018:1-16), 'Nursing a bullet in the human body: Mau-Mau rebels' General Magoto (1927-) and Kenya's quest for independence' (Gathogo 2017a:1-15) and 'The marginalization of women in the African Initiated Churches in South Africa' (Molobi 2008:289-308).

Other publications include, amongst others: 'Mau-Mau rebels' doctor in Mount Kenya East Forest (1952-60): Retrieving the revolutionary history of Milton Munene Gachau' (Gathogo 2017b:32-48), 'Bilingualism in Albert Schweitzer's works and its relevance for Africa' (Gathogo 2016:46-58), 'Ecclesiastical and political leaderships in one armpit: Reconstructing the memory of Thomas Kalume' (Gathogo 2015a:92-110), 'Extremist or an inculturationist? Retrieving Milkah Muthoni's (1948-2009) afro-Pentecostalism' (Gathogo 2014a:191-214), 'Women, come and roast your own ram!' Recollections on Mau-Mau general Chui Wa Mararo (1927-1956) (Gathogo 2014b:102-120), 'Johana Njumbi (1886-1991): The pioneer African leader in Mutira Mission' (Gathogo 2013b:74-95), 'Unsung heroes and heroines at Mutira Mission, Kenya (1907-2012)' (Gathogo 2013c:107-127), 'Mercy Oduyoye as the mother of African women's theology' (Gathogo 2010:1-18), 'The birth of Protestant education in East Africa: Sampling Johannes Ludwig Krapf (1810-1881)' (Gathogo 2009a:167-192), 'Reading John Calvin in African context: Any relevance for social reconstruction of Africa?' (Gathogo 2009b:219-235), 'The history and nature of Gitari's leadership prowess, 1986-91' (Gathogo 2007b:333-347), 'Jesse Mugambi's pedigree: Formative factors' (Gathogo 2006:173-205), 'Dealing with poverty, health and maternal child survival: The Organisation of African Independent Churches perspective' (Molobi 2016) and 'Traumatized between culture and religion: Women's stories' (Landman 2012:1-6).

\section{The case of men battering in Kenya}

Showcasing the men-battering phenomenon in Kenya shows the import of an oral technique perspective, as it points to a trajectory that has become the norm in the 21st century.

In most of his published works, the researcher has relied on oral history technique in order to gather data and eventually demonstrated the power of the people's collective memory in moving society forward. For example, the researcher's article 'Men battering as the new form of domestic violence? A pastoral care perspective from the Kenyan context' (Gathogo 2015b:1-9), published in 2015 based on research that was carried out in 2012, sets out to establish whether men battering has been in African society since time immemorial. How was it handled in the indigenous society when it occurred? What was the cause then and now? Is there anything that can be done to stop it now that it has been experienced overtly since February 2012? Are we sitting on an explosive time bomb? Are we sitting on a volcano that is ready to erupt? (Gathogo 2015b:1-9). The researcher started by collecting data from 26 out of the 47 counties that make up Kenya, after newspapers became awash with cases of men battering by women, a phenomenon that was in contrast with the established trends in domestic violence. In particular, one Friday on 10 February 2012, the headlines of the local Kenyan dailies shocked the entire nation when a photo of a disfigured man in his mid-life was displayed (Gathogo 2015b:1-9). Later it became clear that Mr. Simon Kiguta, a 40-year-old man, had been brutally attacked by his wife of 12 years with a panga (machete). As Ms. Julliana Wairimu fled their matrimonial home for fear of retaliation from the villagers, Mr. Kiguta was taken to Nyeri Provincial Hospital and admitted to the intensive care unit, where he miraculously survived. Shortly after, newspapers and social media splashed photos of another disfigured man, Mr. Francis Muchiri, 34, who openly stated whilst at Mukurweini District Hospital, Nyeri County, on 12 February 2012 that he had been battered by his wife.

In a succession of events, Kenyan men started speaking up and narrating bizarre stories countrywide about their encounters with murderous spouses. In Taita Taveta County, Taita District, Daniel Mulonzi, the area Gender and Social Development Officer, admitted that indeed genderbased violence was rampant in the region - and called for urgent attention (Mnyamwezi 2012:1). In Kisumu, West Kolwa, Western Kenya, Chief Otieno Kabisae reported that he had a number of cases of violence against men by their spouses but regretted that most men preferred to treat their injuries silently so as to avoid being mocked by their fellow men and society at large (Anyuor 2012:1). This drove me to appeal to our collective memory, as oral techniques guided the research in attempting to understand the cultural approaches to addressing men battering throughout the generations. What were the African indigenous ways of addressing men battering in a patriarchal society? Listening to about 200 representatives from 26 counties, out of the 47 that constitute Kenya, yielded interesting approaches that were authentic and creative. The oral narrative technique is certainly essential across the social and human sciences, of which church history is a part. Indeed, oral history techniques are included in the 21st-century skills movement in education, skills that are geared towards problem-solving of cutting-edge issues facing society and that include curriculum revision, the use of science and technology, critical thinking, creative thinking, joint research, collegiality, relevance and contextual-sensitivity, amongst other skills (Gathogo 2015c). Oral history techniques are certainly significant in moving East Africa and the rest of the tropical Africa forward.

\section{Conclusion}

The article has striven to show the power of memory in academia and in social discourse, with particular reference to the African context. With scholars employing diverse theories in their discourses, an appeal to memory remains a critical starting point. In any case, even Isaac Newton (1643-1727) had to appeal to memory in rejecting flattery and praise for his role in formulating the laws of motion and universal gravitation, as he said, '[i]f I can see this far, I must have 
stood on the shoulders of other giants', referring to his predecessors in the scientific discoveries of the 17th century such as Galileo Galilei (1564-1642) (Gathogo 2017c:xix-xx).

Considering that memory is the origin of everything, our methodology in modern forms of learning has to factor in oral techniques as equally credible. The fight against coronavirus disease 2019 (COVID-19) is a good point of reference, as we see many Africans appealing to African indigenous resources as they combat it and are successful to a large extent. With books of plays, novels, church history textbooks and academic journals appealing to oral techniques, memory as the origin of everything becomes the major driving force in academic discourse. Similarly, several theses and dissertations have employed autobiographical methods and theory to unveil the critical cutting-edge issues facing society. This demonstrates the power of memory in moving humanity to the next progressive level. As noted in our introduction, autobiographical memory is a memory system that consists of episodes recollected from an individual's life and is based on experiences, events that took place at a particular time in history and general facts about history. This method is critical for unveiling the concerns of our contemporary world. Church historians cannot escape it in their scholarly discourse. In a nutshell, this article has brought to the fore the fact that memory is not linked to interest alone, as experiences and key events also have their part as well.

On the whole, the article has ably deconstructed the notion that the only reliable and trustworthy way of remembering, learning and teaching, is the written word. It has also demonstrated that oral history techniques can take the form of autobiographies, festschrifts, memoirs, plays and other literary works that mimic unpleasant communal realities. Oral techniques in history have captured several themes, including suppressed histories of gender (in)justice, colonial actualities, neocolonialism, domestic violence and other cutting-edge issues facing society. Barry Denenberg's book Nelson Mandela: 'No Easy Walk to Freedom' (2014), which utilises the autobiographical approach, has also been cited to demonstrate the power of memory in modern academic discourse. The author has also borrowed from his own works to demonstrate the power of oral techniques in modern scholarship. Some of the literary works cited include Ngugi wa Thiong'o's Wizard of the Crow (2006) and Dreams in a Time of War (2010) and Wole Soyinka's The Years of Childhood (1981). In view of this, oral history techniques, in their diverse forms, have been displayed as a critical methodology in the 21st century.

\section{Acknowledgements}

The author would like to thank the peer reviewers for their thorough assessment of the article, which helped greatly in improving it from its original form. The author would also like to thank the Research Institute for Religion and Theology (RITR) of the University of South Africa for the 2020 research output that promoted this research.

\section{Competing interests}

The author declares that he has no financial or personal relationships that may have inappropriately influenced him in writing this research article.

\section{Author's contributions}

J.M.G. is the sole author of this research article.

\section{Ethical considerations}

This article followed all ethical standards for research without direct contact with human or animal subjects.

\section{Funding information}

The author acknowledges the Research Institute of Religion and Theology (UNISA) for its research output of 2020 that made it possible for him to complete this task.

\section{Data availability}

Data sharing is not applicable to this study as no new data were created or analysed in this article.

\section{Disclaimer}

The views and opinions expressed in this article are those of the author and do not necessarily reflect the official policy or position of any affiliated agency of the author.

\section{References}

Anyuor, N., 2012, 'Unreported cases of male battering in Nyanza', The Standard, viewed 08July2012, from http://www.standardmedia.co.ke/?articlelD=2000052337\&story title=Unreported-cases-of-male-battering-in-Nyanza.

Bryman, A., 2004, Social research methods, Oxford University Press, Oxford.

Chidester, D., Kwenda, C., Petty, R., Tobler, J. \& Wratten, D., 1997, African traditional religion in South Africa: An annotated bibliography, Greenwood Press, London.

Cone, J.H., 1975, God of the oppressed, Seabury, New York, NY.

Crotty, M., 2003, The foundations of social research, Sage, London.

Denenberg, B., 2014, Nelson Mandela's no easy walk to freedom, Scholastic Inc. New York, NY.

Elliot, C., 1957, Christian praise, Tyndale Press, London.

Gathogo, J., 2001, The truth about African hospitality: Is there hope for Africa? The Salt, Mombasa.

Gathogo, J., 2006, 'Jesse Mugambi's pedigree: Formative factors', Studia Historiae Ecclesiasticae XXXII(2), 173-205.

Gathogo, J., 2007a, 'Story-telling as a methodology in developing a theology of reconstruction', Studia Historiae Ecclesiasticae 33(1), 155-186.

Gathogo, J., 2007b, 'The history and nature of Gitari's leadership prowess, 1986-91', Churchman 121(4), 333-347.

Gathogo, J., 2008, 'Genesis, methodologies, and concerns of African theology of reconstruction', Theologia Viatorum 32(1), 23-62.

Gathogo, J., 2009a, 'The birth of protestant education in East Africa: Sampling Johannes Ludwig Krapf (1810-1881)', Studia Historiae Ecclesiasticae XXXV(Supplement), 167-192.

Gathogo, J., 2009b, 'Reading John Calvin in African context: Any relevance for social reconstruction of Africa?', Studia Historiae Ecclesiasticae 35(2), 219-235.

Gathogo, J., 2010, 'Mercy Oduyoye as the Mother of African women's theology', Thelogia Viatorum: Journal of Theology and Religion in Africa 34(1), 1-18.

Gathogo, J., 2012, 'Reconciliation paradigm in the post-colonial Africa: A critical analysis', Journal of Religion \& Theology 19(1-2), 74-91. https://doi. org/10.1163/15743012-12341235

Gathogo, J., 2013a, 'The birth of protestant education in East Africa: Sampling Johannes Ludwig Krapf 1810-1881)', Studia Historiae Ecclesiasticae 35(1), 167-192. 
Gathogo, J., 2013b, 'Johana Njumbi (1886-1991): The pioneer African leader in Mutira Mission', The Oral History Journal of South Africa 1(1), 74-95. https://doi. org/10.25159/2309-5792/1596

Gathogo, J., 2013c, 'Unsung heroes and heroines at Mutira Mission, Kenya (1907-2012)', Studia Historiae Ecclesiasticae 39(1), 107-127.

Gathogo, J., 2014a, 'Extremist or an inculturationist? Retrieving Milkah Muthoni's (1948-2009) afro-Pentecostalism', Studia Historiae Ecclesiasticae 40(1), 191-214.

Gathogo, J., 2014b, “'Women, come and roast your own ram!" Recollections on MauMau General Chui Wa Mararo (1927-1956)', The Oral History Journal of South Africa 2(1), 102-120. https://doi.org/10.25159/2309-5792/1586

Gathogo, J., 2015a, 'Ecclesiastical and political leaderships in one armpit: Reconstructing the memory of Thomas Kalume', Studia Historiae Ecclesiasticae 41(3), 92-110. https://doi.org/10.25159/2412-4265/451

Gathogo, J., 2015b, 'Men battering as the new form of domestic violence? A pastoral care perspective from the Kenyan context', Practical Theology [Journal] in South
Africa, HTS Teologiese Studies/Theological Studies 71(3), 1-9. https://doi. Africa, HTS Teologiese Studie
org/10.4102/hts.v71i3.2795

Gathogo, J., 2015c, Pedagogy of the teaching profession: Introducing the new skills movement, Lambert, Saabrucken.

Gathogo, J., 2016, 'Bilingualism in Albert Schweitzer's works and its relevance for Africa', The Oral History Journal of South Africa 4(1), 46-58, 54. https://doi. org/10.25159/2309-5792/1795

Gathogo, J., 2017a, 'Nursing a bullet in the human body: Mau-Mau Rebels' General Magoto (1927 -) and Kenya's quest for independence', The Oral History Journal of South Africa 5(1), 1-15. https://doi.org/10.25159/2309-5792/2004

Gathogo, J., 2017b, 'Mau-Mau rebels' doctor in Mount Kenya East Forest (1952-60): Retrieving the revolutionary history of Milton Munene Gachau', The Ora History Journal of South Africa 5(1), 32-48. https://doi.org/10.25159/2309$5792 / 2004$

Gathogo, J., 2017c, Beyond Mount Kenya region: 40 years of theological \& practical education at St. Andrew's College, Kabare (1977-2017), Evangel, Nairobi.

Gathogo, J., 2018, 'Nahashon Ngare Rukenya and the moral Re-armament in Kenya: The turning point and the resettlement of post war victims (1959-1970)' Studia Historiae Ecclesiasticae 44(2), 1-16. https://doi.org/10.25159/2412 $4265 / 3100$

Gathogo, J., 2019a, 'Steve de Gruchy's theology and development model: Any dialogue with the African theology of reconstruction?', Stellenbosch Theological Journal 5(3), 307-328. https://doi.org/10.17570/stj.2019.v5n3.a15

Gathogo, J., 2019b, 'Mwendoni-ire Z K: Reconstructing the memory of Z.K. Matthews in Southern Africa (1901-68)', Jumuga Journal of Education, Oral Studies, and Human Sciences 2(1), 1-16. https://doi.org/10.35544/jjeoshs.v2i1.13

Gathogo, J., 2019c, 'Theological education in the Tropical Africa: An essay in honor of Christina Landman and a Kenyan perspective', HTS Teologiese Studies 75(1), 1-9. https://doi.org/10.4102/hts.v75i1.5194

Gathogo, J., 2020a, 'A brave one legged general: The story of Mau-Mau General Kassam Gichimu Njogu', HTS Teologiese Studies 76(4), 1-7. https://doi. org/10.4102/hts.v76i4.6155

Gathogo, J., 2020b, 'Karubiu wa Munyi and the Making of Modern Kirinyaga, Kenya', HTS Teologiese Studies 76(4), 1-8. https://doi.org/10.4102/hts.v76i4.6198

Gathogo, J., 2020c, Contemporary theologies: An African perspective, Kairos, Nairobi.
Gathogo, J. \& Njogu, C., 2019, Chui wa Mararo: Mau-Mau General who was burnt into ashes, Kairos, Nairobi.

Idowu, I., 1973, African traditional religion: A definition, S.C.M. Press, London.

Landman, C., 2012, 'Traumatized between culture and religion: Women's stories', HTS Teologiese Studies 68(2), 1-6. https://doi.org/10.4102/hts.v68i2.1147

Mnyamwezi, R., 2012, 'Husband battering also widespread at the coast', The Standard, viewed 08 July 2012, from http://www.standardmedia.co.ke/?articlelD= 2000052359\&story_title=Husband-battering-also-widespread-at-the-Coast.

Molobi, V., 2008, 'The marginalization of women in the African initiated churches in South Africa', Studia Historiae Ecclesiasticae 34(1), 289-308.

Molobi, V.M.S., 2016, 'Dealing with poverty, health and maternal child survival: The Organisation of African Independent Churches perspective', Verbum et Ecclesia 37(1), 1-8. https://doi.org/10.4102/ve.v37i1.1521

Muhia, J.M. \& Gathogo, J., 2018, 'The use of indigenous resources in environmental conservation in Ngugi wa Thiong'o's Murogi wa Kagogo: A religio-cultural perspective', Jumuga Journal of Education, Oral Studies, and Human Sciences 1(1) 1-16. https://doi.org/10.35544/jjeoshs.v1i1.1

Mugambi, J.N.K., 1989, African Christian theology: An introduction, Longman, Nairobi.

Mugambi, J.N.K., 1995, From liberation to reconstruction: African Christian theology after cold war, EAEP, Nairobi.

Niebuhr, R., 1941, The meaning of revelation, Macmillan, New York, NY.

Obama, M., 2020, Transcript of Michelle Obama commencement address, viewed 12 January 2020, from https://www.chicagotribune.com/news/ct-michelleobama-commencement-address-transcript-20150609-story.html.

Parrinder, G., 1962, African traditional religion, Sheldon Press, London.

Phiri, I., 1997, 'Doing theology in community: The case of African women theologians in the 1990's', Journal of Theology for Southern Africa 99(1), 68-76.

Phiri, I., 2004, 'Southern Africa', in J. Parratt (ed.), An introduction to third world theologies, pp. 156-161, Cambridge University Press, Cambridge.

Roberts, B., 2002, Biographical research, Open University Press, Buckingham.

Soyinka, W., 1981, The years of child hood, Vintage, London.

Soyinka, W., 1999, The burden of memory, the muse of forgiveness, University Press, Oxford.

Soyinka, W., 2000, The scars of memory and the scales of justice, Olof Palme Memorial Lecture, Taylor Institution, University of Oxford, 16 November 2000.

Wa Thiong'o, N., 1965, The river between, East African Education Publishers, Nairobi.

Wa Thiong'o, N., 1972, Homecoming, Heinemann, London.

Wa Thiong'o, N., 1983, Barrel of a pen: Resistance to repression in Neo-Colonial Kenya, Africa World Press, Trenton.

Wa Thiong'o, N., 1981, 1986, Decolonising the mind, East African Educational Publishers (EAEP), Nairobi.

Wa Thiong'o, N., 1998, Penpoints, gunpoints, and dreams: Towards a critical theory of the Arts and the state in Africa, Clarendon Press, Oxford.

Wa Thiong'o, N., 2006, Wizard of the Crow, Vintage, London.

Wa Thiong'o, N., 2010, Dreams in a time of war, Harvill Secker, London. 